\title{
Do segredo à fofoca: mulheres que reescrevem a história na poesia brasileira contemporânea
}

\author{
Danielle Magalhães ${ }^{1}$ (i) 0000-0002-0067-931 1 \\ 'Universidade Federal do Rio de Janeiro, Programa de Pós-Graduação em Letras, \\ Rio de Janeiro, RJ, Brasil. 21941-917 - posciencialit@letras.ufrj.br
}

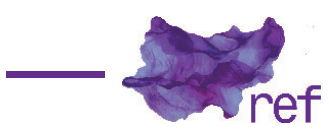

Resumo: A partir da leitura de alguns poemas de poetas brasileiras contemporâneas, neste artigo, proponho uma rasura da noção de "segredo", com base no texto "A literatura no segredo", de Jacques Derrida (2013), pensando a "fofoca" (gossip), teorizada por Silvia Federici (2017; 2019a) em Calibã e a bruxa e em A história oculta da fofoca, como uma reescrita da história hegemônica, colonial e patriarcal.

Palavras-chave: poesia; filosofia; história; segredo; fofoca; Silvia Federici

From Secret to Gossip: Women Who Rewrite History in Contemporary Brazilian Poetry

Abstract: Based on the reading of some poems by contemporary Brazilian women poets, this article proposes an erasure of the notion of "secret", based on the text "Literatura no segredo", by Jacques Derrida (2013), thinking about "gossip", theorized by Silvia Federici (2017; 2019a) in Calibã e a bruxa and in A história oculta da fofoca, as a rewrite of hegemonic, colonial and patriarchal history. Keywords: Poetry; Philosophy; History; Secret; Gossip, Silvia Federici

Del secreto al chisme: mujeres que reescriben la historia en la poesía brasileña contemporánea Resumen: A partir de la lectura de algunos poemas de poetas brasileñas contemporáneas, este artículo propone borrar la noción de "secreto", a partir del texto "Literatura no segredo", de Jacques Derrida (2013), pensando en "chismes" (gossip, fofoca), teorizado por Silvia Federici (2017; 2019a) en Calibã e a bruxa y en A história oculta da fofoca, como reescritura de la historia hegemónica, colonial y patriarcal.

Palabras clave: poesía; filosofía; historia; secreto; chisme; Silvia Federici

"Aquela que revirou dez mil vezes sete vezes sua língua na boca antes para não falar, ou ela está morta, ou ela conhece mais sua língua e sua boca do que todos." (Hélène CIXOUS, 2017, p. 145-146)

\section{O deslocamento como método}

Hoje eu vou contar uma história para vocês. Ou melhor: uma fofoca. Não vou dizer que é segredo, porque o segredo a Deus pertence. Como podemos ler em "A literatura no segredo", ensaio presente no livro Dar a Morte [Donner la mort], em tradução de Fernanda Bernardo, um dos modos como Jacques Derrida (2013) lê a literatura é por um segredo inaugural, o segredo entre Deus e Abraão. Vocês devem saber que Deus exigiu a Abraão o sacrifício do filho de Abraão com Sara, Isaac. Abraão não contou esse segredo para ninguém, nem mesmo para Sara: "Do apelo e da ordem singulares de Deus, Abraão não diz nada a ninguém. Nem a Sara, nem aos seus, nem aos homens em geral" (DERRIDA, 2013, p. 157, grifo do autor). Sabemos que, no final das contas, Abraão não sacrificou Isaac: na iminência do sacrifício, com a faca em punho e a mão estendida, Abraão é surpreendido pelo Anjo do Senhor: "Não toque no rapaz", disse o Anjo. "Não Ihe faça nada. Agora sei que você teme a Deus, porque não me 
negou seu filho, o seu único filho" (BÍBLIA ONLINE, Gênesis 22:11,12). Deus queria a prova de que Abraão o temia, de que Abraão Ihe obedecia. O segredo entre Deus e Abraão sela, portanto, a obediência e o temor de Abraão a Deus.

Gostaria de propor o deslocamento do ponto de vista dessa história: e se contássemos essa história do ponto de vista de Isaac, que viu seu pai empunhar a faca, mas permaneceu em silêncio? E se contássemos essa história do ponto de vista de Sara, que morreu sem saber que seu filho seria sacrificado pelo seu próprio marido em nome de uma obediência cega ao capricho do Deus onipotente?

Um deslocamento do ponto de vista não significa a negação da leitura de Derrida, não significa a discordância do que é o segredo em Derrida, mas a possibilidade de ler esse texto específico de Derrida por um outro ponto de vista, extraindo consequências éticas dele. Esse é o método de Silvia Federici (2017) em Calibã e a bruxa, por exemplo, que discorre sobre a "transição" do feudalismo para o capitalismo sob um ponto de vista que não nos foi contado, o ponto de vista das mulheres. Podemos ver esse método também em Grada Kilomba (PINA 2019), autora de Memórias da plantação: episódios de racismo cotidiano, na exposição Desobediências poéticas, ocorrida entre julho e setembro de 2019 na Pinacoteca de São Paulo.

Desobediências poéticas é composta por duas videoinstalações, cada uma constituída de dois vídeos, correspondendo ao primeiro volume da obra intitulada Illusions, composta pelos subtítulos "Narciso e Eco" (Narcissus and Echo, 2017) e "Édipo" (Oedipus, 2018). Nesses vídeos, Grada reconta de outro modo dois mitos fundadores da cultura ocidental. Em "Narciso e Eco", escutamos o narcisismo da branquitude. Em "Édipo", escutamos, no mito fundador do desejo, que "poder não saber" é um privilégio que mata. Na história do desejo, escutamos pela primeira vez a ênfase no genocídio daqueles e daquelas que são mortos à custa desse "não-saber". Rasurando a história da família real, Kilomba (PINA_, 2019) inscreve a história dos que são mortos. No mito fundador do desejo, escutamos não o desejo, mas a violência do "não-saber" que faz do mito fundador do desejo uma história, sobretudo, de genocídio. Rasurando a história da família real, rasurando o mito fundador do desejo pela psicanálise, Kilomba (PINA_, 2019) rasura, também, o motor que move a filosofia desde tempos remotos, o "não-saber" socrático pelo qual se constrói o saber. É certo que esse "não-saber" teve e tem sua função propulsora ao pensamento, mas o que o ponto de vista de Kilomba (PINA_, 2019) atenta é que só privilegiados podiam construir um saber em cima de um "não-saber". Aqueles e qquelas que não pertenciam ao domínio público, as mulheres, por exemplo, estavam excluídas/os desse "não-saber" que, na filosofia grega, feita por homens, era a porta de entrada do conhecimento.

Recontar dois mitos fundadores do Ocidente sob outro ponto de vista é um gesto de reescrever a história. No caso de Kilomba (PINA, 2019), é uma mulher negra, historicamente violentada, que reescreve a história. Historicamente, as mulheres sempre foram relegadas aos cantos, ao fora da política, ao fora do espaço público, aos confins subterrâneos da casa, ao silêncio. Todavia, elas burlavam esse silêncio do modo como conseguiam. Na prosa, já temos algumas referências de obras que recontaram mitos clássicos, como, por exemplo, Cassandra e Medea, de Christa Wolf (2007; 1998), e A Odisseia de Penélope, de Margaret Atwood (2005). Como a poesia tem realizado esse gesto? O que seria reescrever a história por essas versões que, provavelmente, seriam relegadas pela filosofia como "historinhas" de sofistas?

Em Calibã e a bruxa, a filósofa Silvia Federici (2017) menciona a palavra fofoca (gossip), nos dizendo que, na Idade Média, essa palavra significava "amiga", e que, no período da Inquisição, na chamada "caça às bruxas", essa palavra "mudou de significado, adquirindo uma conotação depreciativa" (p. 335). Como continua Federici, isso foi "mais um sinal do grau a que foram solapados o poder das mulheres e os laços comunais" (p. 335). Em A história oculta da fofoca, texto traduzido por Heci Regina Candiani, publicado como um minilivro pela editora Boitempo como parte do livro Mulheres e caça às bruxas (FEDERICI, 2019b), Federici (2019a) diz que, por meio dessa palavra, gossip,

podemos acompanhar dois séculos de ataques contra as mulheres no nascimento da Inglaterra moderna, quando uma expressão que usualmente aludia a uma amiga próxima se transformou em um termo que significava uma conversa fútil, maledicente, isto é, uma conversa que provavelmente semearia a discórdia, o oposto da solidariedade que a amizade entre mulheres implica e produz. Imputar um sentido depreciativo a uma palavra que indicava amizade entre as mulheres ajudou a destruir a sociabilidade feminina que prevaleceu na Idade Média, quando a maioria das atividades executadas pelas mulheres era de natureza coletiva e, ao menos nas classes baixas, as mulheres formavam uma comunidade coesa que era a causa de uma força sem-par na era moderna (FEDERICl, 2019a, p. 3).

Recuperar, aqui, o termo "fofoca", significa dar uma nova dimensão a ele, desativando a carga pejorativa pela qual as mulheres foram capturadas e o afirmando de outro modo. Torcendo ao limite o sentido dessa palavra, confere-se a ela uma positividade de um lugar de invenção. Assim, mais do que ir contra - pois ir contra é ainda preservar, reativamente, aquilo 
contra o qual se vai -, dar um novo uso é desativar o sentido a que o termo estava preso, liberando as mulheres dessa relação de captura ao transformar a posição depreciativa em um lugar de invenção. Nessa nova dimensão que se abre nesse novo uso, confere-se à fofoca um lugar de invenção e, às mulheres, um lugar de começo, de possibilidade de poder começar, de escrever sua própria história, transformando esse lugar de subterrânea, preterida, rejeitada, renegada, banida, secundária, obscura, esquecida.

Transformar o sentido da palavra "fofoca" também é, de acordo com o trecho citado acima, uma tentativa de voltar ao significado que a atrelava a laços comunais, à ideia de comunidade, de uma comunidade de mulheres não definida senão pelo vínculo que as unia, a amizade, como podemos ler no trecho em que Federici discorre sobre o significado do termo gossip:

Derivada dos termos ingleses arcaicos God [Deus] e sibb [aparentado], gossip significava, originalmente, god parent [padrinho ou madrinha], pessoa que mantém uma relação espiritual com a criança a ser batizada. Com o tempo, entretanto, o termo passou a ser usado em sentido mais amplo. Na Inglaterra do início da era moderna, gossip se referia às companhias no momento do parto, não se limitando à parteira. Também se tornou um termo para amigas mulheres, sem conotação necessariamente derrogatória. Em todo caso, a palavra tinha fortes conotações emocionais. Reconhecemos isso quando observamos a palavra em ação, denotando os laços a unir as mulheres na sociedade inglesa pré-moderna (FEDERICl, 2019a, p. 3-4).

A importância da recuperação desse sentido recai ainda mais no fato de que a ênfase dessa aliança é dada a comunidades de mulheres de classes baixas, essas que, no século XVI, sofreram os maiores ataques por acusações de bruxaria e desobediência aos maridos (FEDERICl, 2019a, p. 7). Federici atualiza essa violência na contemporaneidade ao se referir a ataques contra mulheres, especialmente negras, pobres, proletárias, e à "política de encarceramento em massa que o governo dos Estados Unidos pratica internamente e em todo o mundo" (FEDERICl, 2019a, p. 14). Um dos aspectos desses ataques "é dirigido contra possíveis mães de uma juventude rebelde" (FEDERICI, 2019a, p. 14), diz Federici, o que leva essas mulheres a serem diretamente relacionadas à rebeldia, à desobediência, tal como eram as mulheres satirizadas pelo termo gossip, como aquelas que transmitem um modo de ser como uma herança que passa de mãe para filha, de geração para geração.

Diante do que foi exposto, o deslocamento que propõe a rasura do segredo pela fofoca implica três proposições: 1) se, no texto em questão de Derrida, o segredo se relaciona com uma linhagem patriarcal, rasurar o segredo pela fofoca é rasurar a linhagem patriarcal; 2) rasurar o segredo pela fofoca é rasurar o centro e a figura da centralidade e da autoridade, no caso, Deus: rasurar o centro é, pois, deslocar a atenção do centro para a margem, ou seja, de Deus para as mulheres; 3) rasurar o segredo pela fofoca é rasurar a verticalidade das relações: enquanto o segredo é caracterizado pela verticalidade da relação do homem com o divino, a fofoca é caracterizada pela horizontalidade das relações comunais entre mulheres. Assim, partindo do deslocamento do ponto de vista como método, consideraremos essas outras versões da história - o que, com base nas proposições de Silvia Federici (2019a), poderíamos chamar de "fofoca" -, como uma reescrita da história, uma reescrita que é, a um só tempo, uma escrita de uma política outra enquanto instauração de um começo a quem, historicamente, nunca pôde começar.

\section{Desobedecer para ser}

Em 2018, foi publicado, na Revista Escamandro, o poema "A Mulher de Lot", de Assionara Souza (2018), poeta, escritora, dramaturga que, infelizmente, faleceu no mesmo ano de 2018 , vítima de um câncer. Menos de um mês antes de seu falecimento, sem saber da doença que iria tirá-la de nós, eu lia esse poema no site da revista. Assionara Souza (2018) compõe um coro de mulheres que escreveram poemas que desconstroem o episódio bíblico da mulher de Lot, como Anna Akhmátova e Wislawa Szymborska (2011), por exemplo, em traduções de Lauro Machado Coelho e Regina Przybycien. Essas mulheres desconstroem enquanto reescrevem o destino de Lot, condenada a virar uma estátua de sal por transgredir a ordem de lavé de não olhar para trás:

Um passo atrás

Enquanto a cidade desaba

Todos correndo

Um tumulto dos diabos

O filho, a filha, o marido 
A vizinha da frente - com quem o infeliz tem fornicado

Há mais de cinco anos embaixo de seu nariz

Como se ela não soubesse

Como se ela não tivesse visto de tudo nessa vida

Ele perguntando se a camisa vermelha

- Aquela com um só bolso no lado direito?

- Sim. Essa mesma.

Se a camisa vermelha não estava limpa e bem passada

E o filho indo no mesmo caminho

Tratando-a feito lixo

- A mãe não sabe pronunciar a palavra "estultícia". Tenta, mãe!

Estúpidos todos

Até a filha, que ela tanto ensinou

Agora andava com um centurião

Um centurião!

Maior desgosto para uma mãe

E depois dessa correria toda

Quando arrumassem pouso

Adivinhem quem prepararia o jantar?

Não teve a menor dúvida

Mirou a cidade em chamas

Uma sensação incrível

Deixar de ser uma mulher de pedra

Seu corpo inteiro puro sal rebrilhando ao sol (SOUZA, 2018, s.p.).

No mito está implicado um gesto de se voltar para trás. A primeira imagem que me ocorreu quando li esse poema foi o gesto do anjo da história, de Walter Benjamin (1987), presente na nona tese, em suas "Teses sobre o conceito da história":

\begin{abstract}
Há um quadro de Klee que se chama Angelus Novus. Representa um anjo que parece querer afastar-se de algo que ele encara fixamente. Seus olhos estão escancarados, sua boca dilatada, suas asas abertas. $O$ anjo da história deve ter esse aspecto. Seu rosto está dirigido para o passado. Onde nós vemos uma cadeia de acontecimentos, ele vê uma catástrofe única, que acumula incansavelmente ruína sobre ruína e as dispersa a nossos pés. Ele gostaria de deter-se para acordar os mortos e juntar os fragmentos. Mas uma tempestade sopra do paraíso e prende-se em suas asas com tanta força que ele não pode mais fechá-las. Essa tempestade o impele irresistivelmente para o futuro, ao qual ele vira as costas, enquanto $\circ$ amontoado de ruínas cresce até o céu. Essa tempestade é o que chamamos progresso ( $\mathrm{p}$. 222-232).
\end{abstract}

Como um corpo que vira pedra ao olhar para trás, como um olho cujo corpo se transforma em pedra ao fitar a cabeça da Medusa, o corpo do anjo da história é impelido para frente, com os olhos, porém, presos à catástrofe que se acumula atrás (BENJAMIN, 1987, p. 226). Penso o gesto da mulher de Lot como o gesto do anjo da história, esse gesto que se volta para o horror, para a barbárie, esse gesto que mira a catástrofe e, por isso mesmo, a história. Detendo-me ao poema de Assionara Souza (2018), penso esse gesto de se virar para trás como um gesto, agora, feito por uma mulher. Voltada para a catástrofe, a mulher de Lot não está voltada senão para a história. É ela, portanto, por uma desobediência, quem enxerga a história. 
Mas o poema também nos dá outro ponto de vista: ele transforma uma história de catástrofe em uma história de libertação da mulher. Lá onde o mito diz que a mulher de Lot virou pedra, o poema nos diz que pedra é o que ela era antes, e mirar a cidade em chamas não foi senão o seu momento de brilhar, de ter uma "sensação incrível", como diz o poema. Com isso, o gesto dessa mulher, escrito pela poeta, passa a ser uma dupla desobediência: uma desobediência a Lot e uma desobediência a uma certa escrita da história, instaurando uma outra escrita, uma outra versão da história. Nessa subversão, essa mulher, que até então não era, que até então era a mulher de Lot, que até então existia enquanto mulher do marido, essa mulher que, enquanto mulher de Lot, sofria como mulher de Lot, nessa subversão, essa mulher deixa de ser a mulher de Lot e passa, finalmente, a ser. Essa subversão confere, portanto, o estatuto de ser à mulher que até então não passava de ser a mulher de Lot.

Há uma frase de Macabéa - mulher, pobre, nordestina - em A hora de estrela, de Clarice Lispector (1998), que diz "Que é que eu faço para conseguir ser possível?" (p. 48). É essa pergunta que, historicamente, muitas mulheres devem ter feito. Ser possível significa existir enquanto possibilidade. Não em um ser enrijecido, não em uma essência, não em um ser sem brechas, indefinido, atravessado, mas em um ser que se faça enquanto possibilidades. E fazer ser possível é poder começar não como quem domina, mas como quem nunca pôde ser, como quem nunca foi possível.

Precisamos escrever um poema cujo título seja o nome que nunca foi dado à mulher de Lot. Segundo fontes duvidosas, ela não é nomeada na Bíblia, mas é chamada de Ado ou Edith em algumas tradições judaicas. Como seria, então, se hoje a história fosse escrita pelo ponto de vista de Ado ou Edith, os supostos nomes da mulher de Lot, essa que é inominada?

\title{
Preferir o que não aconteceu
}

A poeta Mônica de Aquino (2018), no livro Fundo Falso, disse aquilo que a história não nos contou de Penélope:

\author{
Penélope mentirosa \\ De noite desfaz, obediente \\ a fera que a carne abriga \\ e regressa à partida: a espera indefinida.
}

De dia, é outro o desejo

tece a mortalha com o silêncio

de ter de casar-se outra vez

(presa entre duas promessas)

mas Penélope mente: o que quer é a solidão.

A fidelidade é um cão (AQUINO, 2018, p. 21).

Na Grécia Clássica, a pólis era o âmbito estritamente político em que discurso era sinônimo de ação: aqueles que podiam discursar eram aqueles que podiam agir. Agir e discursar eram praticamente a mesma coisa, e significavam, como nos diz Hannah Arendt (2002), em O que é política?, poder começar. As mulheres, as crianças, os escravos, os bárbaros não podiam começar. Só os homens livres podiam começar. Mulheres nunca foram livres. Nunca puderam começar. A história das mulheres faz parte da história de quem nunca pôde começar. As mulheres sempre estiveram ao rés do ser, isso que sempre esteve mais próximo à condição animal de que compartilhavam escravos, crianças, bárbaros. Segundo Aristóteles (2009), em A Política, esses e essas apenas falavam, mas não discursavam, apenas tinham voz como um som que dá sinal de dor ou prazer, mas não tinham linguagem, porque estavam mais próximos à animalidade, 
mais presos à necessidade imediata de sobrevivência (ARISTÓTELES, 2009, 1253a). Assim, esses e essas estavam mais distantes da política à qual pertenciam aqueles que tinham a faculdade da linguagem articulada do discurso e não de um mero som sem sentido e inarticulado como um ruído, um cochicho, um balbucio, um gaguejo, um rosnado, um rugido, um ruído de uma fofoca. Tecendo esse ruído sem sentido, ou esse ruído no sentido, Mônica de Aquino (2018) destece o mito de Penélope. Destecendo a espera, a poeta inscreve um agora, um começo: rasura a obediência e tece uma "Penélope mentirosa", uma Penélope ardilosa que faz da espera um meio de desobedecer, um meio de ser, um meio de jogar, gozar, enganar. É nesse engano, nessa mentira, que Penélope é, que Penélope assume o estatuto de ser, porque é aí que ela deseja. Ser, portanto (no final do primeiro poema, ela diz: "Ulisses, agora, sou eu" (AQUINO, 2018, p. 20)), não diz de uma essência, mas de uma possibilidade de desejar.

"Ulisses, agora, sou eu" traz uma ambivalência: Penélope passa a ser Ulisses, aquele que pode agir, discursar, começar, se aventurar, ou então Penélope dizendo para Ulisses "agora, sou eu", "agora, é a minha vez", "agora, não é só você que é; agora, eu sou". Como diz o último verso de "Penélope Mentirosa", "A fidelidade é um cão", se lembrarmos de Argos, o cão fiel de Ulisses, é como se Penélope dissesse "não sou Argos, não sou seu cão, não sou um cão, não sou um animal; agora, eu sou". Também podemos ler esse verso no sentido pejorativo que a palavra "cão" assume quando associada à representação do diabo. Nesse sentido, é como se Penélope perjurasse a própria ideia de fidelidade, contrapondo-se a ela. Em ambos os sentidos, na traição da fidelidade, afirma-se uma outra existência à Penélope.

Os versos que antecedem o verso "Ulisses, agora, sou eu", do primeiro poema do livro ("Penélope Insone") são: "[Penélope] recusa o passado seus retalhos/ prefere o que ainda não aconteceu" (AQUINO, 2018, p. 20). Em uma passagem de Poética, em tradução de Eudoro de Souza, Aristóteles diferencia o ofício do poeta e do historiador ao dizer: "não é ofício de poeta narrar o que aconteceu; é, sim, o de representar o que poderia acontecer, quer dizer: o que é possível segundo a verossimilhança e a necessidade" (ARISTÓTELES, 1992, 1451b). Na mesma passagem, ele continua:

Com efeito, não diferem o historiador e o poeta por escreverem verso ou prosa (pois que bem poderiam ser postas em verso as obras de Heródoto, e nem por isso deixariam de ser história, se fossem em verso o que eram em prosa) - diferem, sim, em que diz um as coisas que sucederam, e outro as que poderiam suceder (ARISTÓTELES, 1992, 1451b).

Ora, segundo Aristóteles, a história é a narrativa do acontecido e, a poesia, diferentemente dessa, é a possibilidade do que poderia acontecer. A poesia, portanto, é a potência. Escrever a potência, o que poderia ter acontecido, o que poderia acontecer, escrever a possibilidade é, pois, escrever o que ainda não aconteceu, como diz o poema. Preferir o que não aconteceu é escrever como quem destece, como quem tece no movimento mesmo de desfazer, inscrevendo uma história na rasura da outra.

Diferentemente de Aristóteles, penso, porém, o ofício do e da poeta como uma reescrita da história, justamente por eles e elas darem à história a verossimilhança e a necessidade que a história não deu e que não vem do passado ou não só do passado, mas, sobretudo, do presente. A verossimilhança, ou seja, a capacidade de ser crível, de se acreditar, e a necessidade, isso que se passa pela responsabilidade e pela justiça, é a poesia, pelo que parece, que pode dar à história. Uma história que se pretende justa, portanto, deve recorrer à poesia, porque a poesia escreve a possibilidade, isto é, escreve a possibilidade de escrita de um novo começo, escreve a possibilidade de escrita do começo que é necessário e (por que não?) crível. Dizendo de outro modo, a poesia escreve a possibilidade do impossível, transforma o impossível em possibilidade.

Aristóteles chamaria isso de "impossível crível". Mais à frente, na Poética, ele dirá: "Às coisas possíveis, mas incríveis, deve-se preferir as impossíveis, mas críveis" (ARISTÓTELES, 1992, 1460a). É essa escrita do impossível (crível) que a poesia faz ser possível como escrita de uma nova história. E quando ela é mais justa do que a própria história, isso significa que a história ainda precisa muito da poesia - e a História Antiga, da qual sabemos, sobretudo, pelo mito, pela poesia, pela literatura, ainda precisa muito da poesia contemporânea, dessa poesia por onde passa aquilo que é dito subversivamente como um cochicho que se propaga, como uma fofoca que se espalha e a qual já não se pode controlar. Incontrolável, dissemina-se a escrita do necessário, do justo e da possibilidade de ser àquelas e àqueles que nunca tiveram o estatuto de ser. Se a história se quer justa e necessária, ela não pode não escutar o que se passa ao largo da história: as fofocas.

\section{0 que sussurram as mulheres}

Como o poema anterior, o poema a seguir, "os clássicos", de Helena Zelic (2018), presente no livro Durante um terremoto, trabalha a partir de um tema, como diz o próprio título, clássico. Não apenas isso: ele trata, igualmente, de uma releitura dos gregos. Neste caso específico, de uma releitura que concerne à Safo: 
os clássicos

quem sabe quais seriam

as palavras de Safo

censuradas pelo tempo

[pela igreja católica]

abarcadas como ilhas mudas

pelos colchetes e chaves da história?

quantos beijos na boca

quantas bocas

[quantas? como?]

a despeito de covardes

bibliotecários da moral?

o que sussurravam as mulheres

nos ouvidos?

um mundo em festa.

os fragmentos das letras

são lacunas do encontro

entre uns corpos e outros.

há amores como há embarcações

e somem no mediterrâneo,

enormes e invisíveis.

[um mundo em festa!]

mais que ilhados,

subaquáticos (ZELIC, 2018, p. 32).

Se, cronologicamente, vivemos em um momento derivado da história cristã do mundo, fazendo com que tal determinação molde, de modo imediato e majoritário, o nosso olhar sobre os gregos, o poema se compromete a fazer uma leitura outra, trazendo justamente aquilo que a tradição cristã censurou. Nesse sentido, ir à Safo, contemporaneamente, é ir a uma Safo não cristã, ou seja, não censurada, em busca de uma outra possibilidade da poeta de Lesbos. Que Safo seria essa que uniria o contemporâneo a uma outra possibilidade da antiguidade? O que, de Safo, a história emudeceu? As "chaves da história" operam para abrir ou fechar a interpretação? O que se encontra perdido pelos muitos colchetes abertos para além da perda dos fragmentos? O que, de Safo, foi perdido pelas peripécias do tempo e o que, de seus poemas, o cristianismo rasurou? Eis a pergunta que o poema se propõe a responder. Se, no que restou de Safo, os colchetes indicam o que falta, o que não chegou ao nosso tempo, em Helena, os colchetes indicam o problema, a pergunta e a resposta: enquanto, na primeira estrofe, o que aparece é o motivo da censura ("[pela igreja católica]"), ou melhor, quem estabeleceu a censura de Safo e, de modo geral, dos gregos, provocando uma interpretação demasiadamente interessada, 
na segunda e na última estrofes aparece, mesmo que em forma de interrogação ("[quantas? como?]"), a resposta, "[um mundo em festa!]", como réplica da resposta à pergunta "o que sussurravam as mulheres/ nos ouvidos?/ um mundo em festa". A festa provém daquilo que é sussurrado, cochichado. Como fofoca, esse poema é, portanto, a disseminação da festa que os "covardes/ bibliotecários da moral" censuraram, a divulgação do detalhe que o cristianismo gostaria que fosse ignorado.

Em um dicionário etimológico, encontramos que "fofoca" é a "divulgação de detalhe da vida alheia que o outro gostaria que fosse ignorado" (DICIONÁRIO ETIMOLÓGICO, 2008, s.p.). No livro A influência africana na cultura brasileira, vemos que "fofoca" tem origem africana, do banto, e que o étimo da palavra é discutível: "alguns etimologistas admitem ser do quimbundo fuka, revolver; outros, do bundo fwafoca, invólucro vazio" (Emmanuel SARAIVA, 2016, p. 48). Fazendo com que palavras incertas, de verdades tão somente desconfiadas, sem fundamento, possam circular sem ancoragem, propiciando que outras histórias sejam contadas, "invólucro vazio" é isso que não deixa apreender uma determinação, qualquer seja, de verdade única, totalizante, exclusiva. Sendo o "invólucro vazio" a sua força-motriz, a fofoca como isso que não provém de uma origem e de um centro fixados é, incessantemente, o revolvimento de camadas segmentadas e cristalizadas da história. Daí que fofocar é revolver a história. Assim podemos ler a segunda metade do poema de Helena Zelic como uma resposta ao que foi colocado na primeira metade: a estrofe "o que sussurravam as mulheres/ nos ouvidos?/ um mundo em festa", estrofe que contém uma pergunta e uma resposta, passa a ser então um divisor de águas no próprio poema; a partir daí ele se faz como uma resposta às perguntas das primeiras estrofes, e essa resposta é "o que sussurravam as mulheres".

\title{
Começo descolonial
}

Federici nos diz que, no século XVI, o fortalecimento patriarcal, aliado ao poder da lgreja, pregou a obediência como "a primeira obrigação da esposa", imposta não só pela lgreja, mas pelo direito, pela opinião pública "e, em última análise, pelas punições cruéis que foram introduzidas contra as 'rabugentas', como o scold's bridle [rédea ou freio das rabugentas], também chamado de branks, engenhoca sádica de metal e couro que rasgaria a língua da mulher se ela tentasse falar" (FEDERICI, 2019a, p. 8). Esse instrumento de tortura, também usado em pessoas escravizadas durante a escravidão moderna, "foi criado como castigo para as mulheres das classes baixas consideradas 'importunas' ou 'rabugentas' ou 'subversivas', sempre suspeitas de bruxaria" (FEDERICl, 2019a, p. 9). Diante disso, recuperar a "fofoca" é, antes de tudo, restituir a língua às mulheres, sobretudo, às mulheres historicamente oprimidas e violentadas, como as mulheres pobres e negras.

Em Onde estão as bombas, da poeta e professora Tatiana Pequeno (2019), há um poema que se chama "silva antígona":

\author{
primeiro a poesia foi solapada por \\ um desenho errado que fizeram \\ dela. foi exposta entre os gentios \\ de uma biblioteca eminente sabia \\ mente iluminada ao cifrão mais \\ vantajoso da república quando \\ disseram - ainda tolos - que era \\ engenho ou arte ou descendência \\ a moeda da sua larga circulação. \\ depois a poesia não chegou ao que \\ era o seu destino, a distância, e o \\ que seria munição transformou-se \\ naquilo que o poder engendra na \\ psicologia da servidão voluntária: \\ dor, bicheira, melancolia, exílios,
}


enforcamentos, bactérias, prisão.

agora a poesia tem companhia tem

um número incontável de letras tem

esses nomes que evocam o seu dia

mais ancestral de artesanato e saída.

ela então migrou daquela região grave

e grega onde hoje se deve os fundos da

terra e troca a guarda bem ao nosso lado

entre apertos de mão, palavras sobre crise

(acenos, claro, porque implicar-se é um

gesto permitido pelas normas da saúde)

e ensaios e mais ensaios que jogo ao mar

quando encaro os terminais próximos

do trabalho que não é de libra e recordo

que este é, afinal, o novo antropoceno e

boa será mesmo a poesia que apenas

indique nos seus versos mais rupestres os

caminhos que tenham levado a sabedoria

lírica os rios as violetas e os humanos

mais sensíveis à sua completa extinção (PEQUENO, 2019, p. 14-15).

Com suas assonâncias e aliterações em algumas rimas esparsas em /ia/ e /ão/, estaríamos quase lendo um canto, mas, de cara, nos deparamos com a estranheza do título. Seria o poema uma tragédia? Seria o poema a escrita de uma nova tragédia cuja personagem principal é a poesia, agora como "silva antígona"? No poema, a ancestralidade vem em dois nomes, ou em dois sobrenomes, ou na estranha justaposição de um sobrenome atual a um nome arcaico, ou na antecedência do sobrenome, atual, ao nome, arcaico. Colocando o sobrenome no lugar do nome e o nome no lugar do sobrenome, o atual antecede e, ao mesmo tempo, fica ao lado do mais antigo. Ambos passam a compor, nessa inversão, um nome e um sobrenome, isso que é matéria de transmissão, de linhagem. Sabemos que Antígona é aquela que lutou pelo luto proibido pela lei, aquela que tentou, contra a lei, dar um funeral digno a seu irmão. A respeito da curiosa junção que compõe o título, outro poema do livro nos dá uma pista. O primeiro verso de "cantilena da outra ponta da praia" diz "meu pai era pequeno além de silva" (PEQUENO, 2019, p. 35).

Silva é um dos sobrenomes mais comuns nos brasileiros e brasileiras. Silva também é uma palavra latina que significa mata, floresta, selva, selvagem. Silva são os que podem ser presos. Silva são os que podem ser mortos. A poeta porta essa herança, ela carrega esse sobrenome. Aliás, ela também carrega o adjetivo transformado em sobrenome. Tatiana Pequeno da Silva (2019) traz em si os pequenos e os silvas, os pequenos silvas, os selvagens, os não domesticados.

A junção entre Silva e Antígona, entre Brasil e Grécia, entre gregos, latinos e brasileiros, entre atual e arcaico, entre o mais comum e o mais incomum, entre o sobrenome e o nome, entre os que são mortos e os que têm o desejo de enterrar os mortos, entre os que são mortos e aquela que não deveria ter nascido, entre uma linhagem e aquela que teve a linhagem interrompida, essa junção traz uma ancestralidade fundante da contemporaneidade. Ancestralidade que também surge pela afronta à lei que impede de enterrar os mortos e a lei que chancela a matança dos/ das Silvas - como diz a famosa letra do funk: "era só mais um silva que a estrela não brilha". "[S]ilva antígona" tece um começo, tece uma linhagem que parece ser da própria poesia. Nesta assinatura - "silva antígona" - lemos uma genealogia, uma história da literatura, uma história da poesia que se dá, porém, por/de um erro de origem: "primeiro a poesia foi solapada por/ um desenho errado que fizeram/ dela". Não furtando o olhar à extinção, o poema não só conta 
o começo da poesia como entrevê o futuro dela, e, nesse futuro, a "boa poesia" será aquela cuja "selvageria" nos versos indique, mostre, acene o caminho da extinção de uma matéria que sempre foi tradicionalmente cara à poesia. Os versos finais do poema dizem: "boa mesmo será a poesia que apenas/ indique nos seus versos mais rupestres os/ caminhos que tenham levado a sabedoria/ lírica os rios as violetas e os humanos/ mais sensíveis à sua completa extinção".

Há, em "silva antígona", uma refundação da poesia que passa por referências indiretas a obras fundantes da poesia ocidental, como Os Lusíadas, por exemplo, em que a Europa, de maneira geral, e a Grécia, especificamente, como o berço da épica, assumem, no poema, um estatuto de dívida enquanto lugares de origem. Aqueles que dominaram, que colonizaram, que endividaram, tornam-se aqui os endividados. No poema, lemos também uma refundação da poesia pela mulher: quem encara o mar é uma poeta mulher que, dirigindo-se ao trabalho, e não comandando caravelas, invadindo, colonizando, anuncia o que será, no futuro, a poesia. E o que essa poeta mulher descolonial anuncia é uma poesia-testemunho, uma poesia que seja as marcas de uma ausência, que indique, em si, os caminhos da extinção. "[S]ilva antígona" escreve uma história da poesia em que o futuro da poesia é o trabalho de luto, anunciado do desejo de uma poeta mulher que se dirige ao trabalho e vincula a gestação de um novo começo, de um "novo antropoceno", à poesia por vir.

Se a poesia agora se caracteriza por apertos de mão, palavras sobre crise, acenos, ensaios jogados ao mar, a relação dela com o "novo antropoceno" é intermediada pelo "trabalho que não é de libra", ' pela economia que não move o país, mas por outra economia, que não é do ganho, do acúmulo, do lucro, do progresso, mas de um resto e de um dispêndio que são um envio errante. Como há mares implicados no poema, seja pela referência direta à Grécia, seja, indiretamente, ao Brasil e a Portugal, se nos ativermos aos estilos literários cifrados no poema, podemos pensar que um ensaio jogado ao mar finalmente cumpriria o destino não cumprido da poesia, isto é, a distância. Como uma garrafa com uma mensagem lançada ao mar, a poesia reescreveria a história dos descobrimentos, inscrevendo uma outra história: não a história dos descobrimentos, mas a história da errância e de envios errantes, inseparável de uma história de luto.

\title{
Errar o destino
}

Em resenha na Revista Odara, a poeta, ensaísta e cofundadora da iniciativa Mulheres que escrevem, Taís Bravo (2019), diz sobre o livro O Martelo, de Adelaide Ivánova (2017): "Ao escrever aquilo que testemunham, as poetas [...] [c]olocam em palavras saberes que sempre foram cochichados. Convocam diálogos, filiações, respostas. Expandem possibilidades dentro de um campo que (assim como todos os outros em nossa sociedade patriarcal) ainda precisa ser disputado" (BRAVO, 2019, p. 124). É também sob o estímulo dessa colocação que escrevo este texto, como tentativa de afirmar e desdobrar esse cochicho que Bravo traz. Atrelar o testemunho ao cochicho é justamente relacionar a precariedade do discurso do testemunho a essas que nunca puderam discursar. Trazer o cochicho ao lugar de saber é radicalizar o cochicho como uma nova forma de escrita, como um saber que não é do discurso, mas do cochicho, isto é, do testemunho. Escrever esses cochichos, disseminá-los, dizê-los em voz alta, é uma forma de abalar os discursos e de tornar públicos os testemunhos. Como diz Derrida (2015), "testemunhar, declarar, bearing witness, é sempre tornar público" (p. 39).

A poeta Catia Cernov (2019) é essa que fala na língua do testemunho. "Um testemunho se faz sempre em primeira pessoa", diz Derrida (2015, p. 47), seja na primeira pessoa do singular, seja na primeira pessoa do plural. É falando em primeira pessoa que Cernov (2019) diz, porém, de Helena. O título do poema é "Helenikas":

\author{
Páris \\ Qe tanto amava minha buceta \\ Glorificava minhas tetas tatuadas \\ Me pedia pra empinar a bunda \\ Fabricou um arco \\ E me fez cativa \\ Como se isso provasse amor
}

\footnotetext{
'A referência vem de outro poema presente no livro, intitulado "campo de libra" (PEQUENO, 2019, p. 10). Campo de Libra é o nome que se dá a uma das maiores descobertas já realizadas no pré-sal brasileiro. Ou seja, isso que movimenta a maior economia do país não representa senão a agressão do dinheiro, da exploração, do capitalismo, do acúmulo que não deixa restos.
} 
A gente trepava a tardetoda

Desavergonhados

No centro de Ágora

Lá fora o exército ouvia nossos gemidos\&súplicas

E parecia explodir

Como nosso-gozo

Rastejavamos entre suor\&lama\&sêmen

Me ensinou a ejacular como umamulher

Logo eu,

Tão fina dama predestinada ao rei

Tão delicada flor clássica

Urrava e jorrava na cara dele

Depois

Com seu pênis flácido\&cansado

Ele passava horas alisando o arco

Como qem alisa minhas coxas

Como se tudo fosse amor

Aqele amor secreto à minha buceta

Mas havia uma promessa dguerra pros homens

Qe lá fora escutava mas não gozava

E queria tbm explodir

Por isso me fez cativa

Traiu nossa intimidade absurda

Nosso jogo d amantes

Nossas pernas trançadas\&cúmplices

Nossos brilhantes olhos ddiamantes

Eu ainda dei pra ele

Por mais duas luas

Páris me amava

Me possuía

Me fazia implorar

Ele mesmo implorava 
Nos olhavamos e kopulavamos

Com toda permissão ds deuses

E a testemunha ds exércitos

Qe lá fora esperava e não gozava

Até qe as moscas passaram a sentar

Sobre seu pênis grudento e caído

Enqanto ele fabricava uma flecha

Qando ele fez a flecha

Pra dar vingança aos exércitos qe ouviam e não gozavam

Minha buceta sofreu d solidão

Sabe o qe é se arrastar e pedir o qe deveria ser sincero?

Vcs sabem o qe significa pruma mulher ser carne dguerra?

Alguem faz ideia do qe sente um corpo qe goza intenso

D repente ter d se tornar apenas troféu?

Dói dói dói

Dói meus joelhos sem toque

Eu me agarro a eles e desespero

Como qem revive o toqe e chora pra apagar lembranças

Páris conduzindo exércitos

Lá fora

Aqi dentro

Eu

Qe aprendi a ser puta

Bem safada

Trepar só se for um monte

D repente cinza

Mito

Helenika

É cruel

Então eu fugi

E dei pro primeiro soldado faminto qe encontrei (CERNOV, 2019, p. 60).

"Helenikas" nos conta uma história que não foi bem aquela história de amor que nos foi contada. Nesse vínculo do arcaico com o atual, temos a atualização de Helena. Cernov 
(2019) mostra que reescrever uma história de amor e de guerra que coincide com um dos começos da cultura ocidental é reescrever a história sem papas na língua, é, também, trazer à cena o obsceno, aquilo que ficou de fora da cena. Nas imagens de "tetas", "bunda" e "arcos", não temos senão uma forma arqueada que liga amor e guerra, Eros e Áries. O poema todo é uma oscilação entre Eros e Áries, o erotismo, figurado nos amantes Helena e Páris, e a guerra, figurada no exército que "esperava e não gozava". O amor comparece no poema como um gesto de transgressão: contra o destino de Helena a Menelau, o rei ("Logo eu,/ Tão fina dama predestinada ao rei/ Tão delicada flor clássica"), ela transgride o destino sendo amante de Páris. Depois, quando Páris vai para a guerra lutar com Menelau, a mulher abandonada continua respondendo ao desejo erótico e realiza outro gesto de transgressão: "Então eu fugi/ E dei pro primeiro soldado faminto qe encontrei". Nem o rei nem o príncipe, mas o soldado, o anônimo. Tem-se então o privilégio de Eros sobre Áries em Helena. O que permanece é o erotismo, é a esse que ela irá responder, transgredindo o destino. (2005) diz:

No texto Ver Helena em toda mulher, de tradução de Fernando Santoro, Barbara Cassin

Se forem consultar, por exemplo, o excelente "Dictionnaire Etymologique de la Langue Grecque", de Chantraine (Klincksieck, 1990), vocês saberão que, "qualquer que seja a interpretação tentada pelos historiadores da religião [...], vão procurar uma etimologia" para "Helena". Dito isso, há uma pletora de etimologias, nas quais toda a Grécia acreditou. Por exemplo, "Helena" vem de "helein", infinitivo passado do verbo "haireo", "tomo, rapto, capturo": aí está, dizem todos os gregos, uma boa eponímia, conforme ao "etymon" no sentido verdadeiro, no sentido etimo-lógico da palavra (s.p.)

De acordo com isso, o verso "Então eu fugi", do poema de Cernov (2019), transgride, também, o nome próprio de Helena, desamarrando-a mais uma vez de seu destino: aquela que era destinada a ser capturada fugiu (CASSIN, 2005, s.p.).

Cernov (2019) leva a crer que recontar a história de Helena é atualizá-la em um dizer diferente e, na radicalização desse dizer outro, encontramos transgressões na língua, como quem inventa uma língua cifrada para poder falar, para poder ser lida, como quem muda um pouco a grafia, suprime algumas letras, contrai algumas palavras, junta uma palavra na outra, subvertendo a norma, escrevendo como quem manda um tuíte, por exemplo, e torna público para uma comunidade de leitores e leitoras que, de repente, irão viralizar a mensagem, passando-a adiante. A única intervenção que encontramos de pontuação é onde o ponto de interrogação se torna indispensável: "Sabe o qe é se arrastar e pedir o qe deveria ser sincero?/ Vcs sabem o qe significa pruma mulher ser carne dguerra?/ Alguem faz ideia do qe sente um corpo qe goza intenso/ D repente ter a se tornar apenas troféu?". Na reescrita da história de Helena, novas perguntas são colocadas a uma coletividade: ela se dirige a "Vcs". Nessa história, dizer "eu" é dizer "ela", uma primeira pessoa ficcional: o "eu" que escreve é o "eu" de Helena e o "eu" que lê. Nessa voz de uma mulher que diz "eu" escutamos um "ela" que é, também, um "você, mulher". Catia Cernov (2019) não diz "a Helena", ela diz "eu". Como se estivesse lá, como se fosse ela mesma, como se fosse Helena, como se fosse testemunha, como se, nessa potência, nessa possibilidade, "à maneira da ficção ('como se')" (DERRIDA, 2015, p. 71), a poeta diz, porém, "eu", essa voz em primeira pessoa que geralmente não se alia à ficção, mas ao vivido, ao testemunho.

Atentando para a constituição de ficção no testemunho, Derrida (2015) atenta, igualmente, para a constituição de real na ficção quando diz:

Sem a possibilidade dessa ficção, sem a virtualidade espectral desse simulacro e em seguida dessa mentira ou dessa fragmentação do verdadeiro, nenhum testemunho veraz enquanto tal será possível. Por consequência, a possibilidade de ficção literária é assombrada, como sua própria possibilidade, pelo testemunho dito veraz, responsável, sério, real (p. 81-82, grifo do autor).

Em outras palavras, se a possibilidade do testemunho se passa necessariamente pela ficção, a ficção só é possível se traz em si a possibilidade do testemunho, a possibilidade da carga real, séria, responsável e veraz do testemunho. Quando o poema de Catia Cernov (2019) fala em primeira pessoa, é Cernov, é Helena e é a mulher que lê quem fala. Nós, mulheres, estivemos lá para testemunhar a história que não foi contada. Cada uma de nós pode ser testemunha dessa história e, assim, cada uma de nós pode reescrever a história de Helena, porque reescrever a história de Helena significa reescrever a história de cada uma de nós.

\section{Uma mulher sob risco}

Uma reescrita da história se passa por inventar a história e por reescrever as narrativas dominantes. Essas narrativas não estão restritas aos livros de história, mas devem ser entendidas no campo mais amplo de uma construção de narrativas que se passa por mitologias, filmes, jornais, revistas, televisão, conversas, redes sociais, enfim, tudo o que faz parte da linguagem. 
É assim que o livro Mulher correndo entre ciprestes, de Carolina Pazos (2019), poderia ser, em sua maior parte, uma reescrita, uma refilmagem, uma reencenação de diversos filmes que compõem a história do cinema. Como seriam essas histórias contadas de outro ponto de vista? Mais ainda: do ponto de vista de uma mulher? Mais ainda: do ponto de vista de uma mulher que está sob risco? Trazendo a rasura desde o título, é uma mulher sob risco, sob rasura, que conta uma outra história e dá lugar a muitas outras mulheres e histórias.

Os poemas deste livro não são uma representação dos filmes que são aludidos nos títulos. Pelo contrário, ao ultrapassar os títulos, vemos que há um acontecimento outro. Os filmes são fios que a poeta puxa como ponto de partida que, assumindo todos os riscos, ela risca para encenar aquilo que nunca foi encenado, dando lugar a uma cena que nunca teve lugar na história. "Os homens que não amavam as mulheres", "Terra Fria", "Kill Bill", "O Silêncio dos Inocentes", "Amelie Poulain", "A Árvore da vida", "A vida dos outros", "Sociedade dos poetas mortos", "Que horas ela volta?", "Mandacaru Vermelho" e tantos outros filmes clássicos ou não da história do cinema nacional e internacional vão se transformando na película onde a história de uma mulher é escrita. Vejamos, por exemplo, o que diz uma sinopse de um dos filmes cujo título compõe um poema presente no livro de Carolina, "The witch: a New-England Folktale", traduzido como "A bruxa", lançado no Brasil em 2016: "Em uma fazenda no século XVII, uma histeria religiosa toma conta de uma família que acusa a filha mais velha pelo desaparecimento do seu irmão ainda bebê" (Georgenor NETO, 2018, s.p.). Os primeiros versos do poema de mesmo título dizem: "Sonhei que descobriam meus pecados/ acordei com sangue na garganta/ faz tanto tempo desde a inquisição?" (PAZOS, 2019, p. 8):

THE WITCH: A NEW-ENGLAND FOLKTALE

\author{
Sonhei que descobriam meus pecados \\ acordei com sangue na garganta \\ faz tanto tempo desde a inquisição? \\ não faz tanto desde Ravensbrück \\ os incêndios nas fábricas de tecelãs \\ os estupros em Willbrook \\ são nódoas nesse tecido \\ minha pele presa \\ nas correntes
}

do Tapeka State Hospital

Gisella Perl, as crianças te perdoam

por salvar as grávidas das tropas

Nísia Floresta talvez fizesse o mesmo

Eu apenas murmuro
"não desejo crianças"
da sala para a cozinha
da cozinha para a sala
a frase de Leila Diniz

"transo de manhã, de tarde e de noite"

mas de madrugada eu ainda sonho

a descoberta dos pecados (PAZOS, 2019, p. 8). 
No poema, justapostas à menção à Inquisição, encontramos a ginecologista judia que ajudou centenas de mulheres no campo de concentração, Gisella Perl, encontramos também a educadora feminista Nísia Floresta, encontramos, ainda, a atriz brasileira feminista Leila Diniz em um trecho que vai na contramão da figura da mulher associada à procriação e à maternidade ("Eu apenas murmuro/ 'não desejo crianças'/ da sala para a cozinha/ da cozinha para a sala/ a frase de Leila Diniz/ 'transo de manhã, de tarde e de noite'/ mas de madrugada eu ainda sonho/ a descoberta dos pecados"). O filme, portanto, é apenas um fio que se puxa para convocar mulheres de diferentes épocas, de modo que todas elas passam, agora, a ser protagonistas dessa história que gira em torno de uma inquisição remissiva para além de uma época histórica.

Uma pele muito fina e delicada cobre uma história para dar lugar à outra, às vezes remanescendo uma cena da história inicial, um pequeno detalhe, uma palavra, de onde se desdobra toda uma nova cena. Como um palimpsesto, no risco é que se dá lugar a outro. Cada poema que se inscreve no risco de uma película é a história contada e escrita de outro modo, de outro ponto de vista: do da pele de uma mulher sob risco. Sob tantos riscos, as histórias que são reescritas não inscrevem senão a história de uma mulher que se traça também na abertura de um risco que faz surgir muitas histórias, muitos nomes, muitas mulheres. Dessa mulher singular que se abre a tantas mulheres, dessa singularidade que se abre a uma pluralidade, o "eu" autobiográfico/autoficcional se torna a personagem principal, protagonista dessas histórias que agora passam a ser suas. Essas histórias tomam novos riscos, novos contornos, novas personagens ao serem contadas de novo: contar de novo, recontar é, portanto, contar diferente. Assim, o livro de Carolina Pazos (2019) nos leva a crer que, para que uma mulher transforme a história, ela precisa começar inscrevendo a sua, e a de muitas, sob um olhar a partir do qual nós, mulheres, determinamos como e qual história queremos contar, porque nós sempre estivemos sob o risco da história que é contada por nós.

Acolhendo a invenção, o simulacro, a falta de sentido, o ruído no sentido e a indecidibilidade entre o ficcional e o não ficcional, esses poemas se aliam não à história dos vencedores, mas à história dos vencidos, como reivindicou Walter Benjamin em suas "Teses sobre o conceito da história" (BENJAMIN, 1987, p. 223-224). É nesse sentido que se dá a importante colocação de Flavia Trocoli e Carla Rodrigues em apresentação à tradução de Demorar, a respeito de uma citação de Derrida: "[...] eis o ponto em que a ficção, por ser inapropriável, não totalitária, poderá, num jogo sempre arriscado, se fazer passar por testemunho e fazer (uma pequena) justiça literária aos mortos" (TROCOLI; RODRIGUES in DERRIDA, 2015, p. 15).

Se pensarmos que o mais importante do segredo entre Deus e Abraão não era o conteúdo do segredo, mas a aliança entre eles, aqui, neste caso, podemos dizer que essa poesia, ao contrário da literatura que Derrida pleiteia no texto em questão, escolhe se aliar não com o Deus-todo-poderoso, mas com Sara, a mãe que teve o filho na iminência de ser sacrificado, e com Isaac, a criança que esteve na iminência de ser sacrificada. Se o que mais importa no segredo é a aliança que se estabelece entre os envolvidos, e se Derrida lê a literatura por esse segredo inaugural, a literatura que afirmamos aqui é outra, é aquela que se alia com os sacrificados. Não poderíamos deixar de lembrar a importante obra de Nicole Loraux (1988), Maneiras trágicas de matar uma mulher, e do que ela diz sobre as mulheres sacrificadas nas tragédias gregas estarem sempre fora da cena na hora da morte. Falando da importância da escuta no gênero trágico, Loraux coloca a própria tragédia "sob o signo da escuta" no gesto de analisar as mortes que, apesar de narradas, não eram encenadas, ficavam fora do olhar do público (LORAUX, 1988, p. 8-11). Ao "colocar a tragédia sob o signo da escuta" (LORAUX, 1988, p. 8), Loraux realiza um gesto de escuta: traz à cena o que ficou fora da cena, traz a primeiro plano essas mulheres condenadas a ficarem "longe dos olhos", fora do alcance público, aos confins da casa (LORAUX, 1988, p. 11).

Como os poemas analisados indicaram, para realizarmos esse gesto de escuta, talvez não possamos contar com os segredos da história, porque os segredos da história secretam as mulheres, apartam-nas, sacrificam-nas da história. A literatura que se alia com os que são passíveis de serem mortos e com os que estão passíveis de estarem na perda é uma literatura que precisa, a cada dia, rasurar os segredos da história, revolver as camadas segmentadas da história e reinventar, a cada dia, uma outra história, uma história de desobediências, de possibilidades, de começos. Alguém já começou a propagar essa fofoca. Não sei quem começou, mas é com essa comunidade que eu me alio e faço coro, porque é da fala e não do falo que as mulheres gozam (CASSIN, 2005, s.p.). Como diz a expressão, "quem conta um conto, aumenta um ponto".

\section{Referências}

AKHMÁTOVA, Anna; SZYMBORSKA, Wislawa. "A Mulher de Lot". Traduções de Lauro Machado Coelho e Regina Przybycien. Poemargens, 2011. Disponível em https://poemargens.blogspot. com/2011/09/akhmatova-szymborska.html. Acesso em 12/12/2019. 
AQUINO, Mônica de. Fundo Falso. Belo Horizonte: Relicário, 2018.

ARENDT, Hannah. O que é política? Tradução de Reinaldo Guarany. Rio de Janeiro: Bertrand Brasil, 2002.

ARISTÓTELES. A Política. Tradução de Nestor Silveira Chaves. São Paulo: EDIPRO, 2009.

ARISTÓTELES. Poética. Tradução de Eudoro de Souza. São Paulo: Ars Poética, 1992.

ATWOOD, Margaret. A Odisseia de Penélope. Tradução de Celso Nogueira. São Paulo: Companhia das Letras, 2005.

BENJAMIN, Walter. "Teses sobre o conceito da história". In: BENJAMIN, Walter. Obras escolhidas. Vol. 1. Magia e técnica, arte e política. Ensaios sobre literatura e história da cultura. Tradução de Sérgio Paulo Rouanet. Prefácio de Jeanne Marie Gagnebin. São Paulo: Brasiliense, 1987. p. 222-232.

BÍBLIA ONLINE. Gênesis, 22:11,12. Bíblia online, 2019. Disponível em https://www.bibliaonline. com.br/nvi/gn/22. Acesso em 05/11/2019.

BRAVO, Taís. "O testemunho em 'O Martelo', de Adelaide Ivánova". Revista Odara, Rio de Janeiro, V. 6, n. 7, p. 119-124, 2019.

CASSIN, Barbara. "Ver Helena em toda mulher". Tradução de Fernando Santoro. Folha de São Paulo, 17/07/2005. Disponível em https://www1.folha.uol.com.br/fsp/mais/fs1707200506.htm. Acesso em 16/11/2019.

CERNOV, Catia. "Helenikas". Revista Cult, São Paulo, n. 1, p. 60, 2019. (Antologia Poética)

CIXOUS, Hélène. "O riso da Medusa". In: BRANDÃO, Izabel et al. (Orgs.). Traduções da cultura: perspectivas feministas (1970-2010). Florianópolis: Editora da UFSC, 2017. p. 129-155.

DERRIDA, Jacques. "A literatura no segredo: uma filiação impossível”. In: DERRIDA, Jacques. Dar a Morte. Tradução de Fernanda Bernardo. Coimbra: Palimage, 2013.

DERRIDA, Jacques. Demorar: Maurice Blanchot. Tradução de Flavia Trocoli e Carla Rodrigues. Florianópolis: Editora da UFSC, 2015.

DICIONÁRIO ETIMOLÓGICO. "Fofoca". In: Dicionário Etimológico. Matosinhos: 7Graus, 2008. Disponível em https://www.dicionarioetimologico.com.br/fofocal. Acesso em 05/1 1/2019.

FEDERICI, Silvia. Calibã e a bruxa: mulheres, corpo e acumulação primitiva. Tradução de Coletivo Sycorax, Aline Sodré, Cecília Rosas, Juliana Bittencourt, Leila Giovana Izidoro, Lia Urbini e Shisleni de Oliveira-Macedo. São Paulo: Elefante, 2017.

FEDERICl, Silvia. A história oculta da fofoca: mulheres, caça às bruxas e resistência ao patriarcado. Tradução de Heci Regina Candiani. São Paulo: Boitempo, 2019a.

FEDERICl, Silvia. Mulheres e caça às bruxas: da ldade Média aos dias atuais. Tradução de Heci Regina Candiani. São Paulo: Boitempo, 2019b.

IVÁNOVA, Adelaide. O Martelo. Rio de Janeiro: Garupa, 2017.

KILOMBA, Grada. "Desobediências poéticas”. Pina_, Pinacoteca de São Paulo, jul.-set. 2019. (Curadoria de Jochen Volze Valéria Piccoli). Disponível em http://pinacoteca.org.br/programacao/ grada-kilomba-desobediencias-poeticas/.

LISPECTOR, Clarice. A hora da estrela. Rio de Janeiro: Rocco, 1998.

LORAUX, Nicole. Maneiras trágicas de matar uma mulher: imaginário da Grécia Antiga. Tradução de Mário da Gama Kury. Rio de Janeiro: Jorge Zahar Editor, 1988.

NETO, Georgenor Franco. "Um terror de mal-estar". Cinepop, 2018. Disponível em https://cinepop. com.br/critica-a-bruxa-netflix-lanca-polemico-terror-satanico-179073. Acesso em 05/1 1/2019.

PAZOS, Carolina. Mulher correndo entre ciprestes. São Paulo: Urutau, 2019.

PEQUENO, Tatiana. Onde estão as bombas. Juiz de Fora: Macondo, 2019. 
SARAIVA, Emmanuel de Jesus. A influência africana na cultura brasileira. Joinville: Clube de Autores, 2016.

SOUZA, Assionara. "A Mulher de Lot". Escamandro: poesia, tradução, crítica, 2018. Disponível em https://escamandro.wordpress.com/2018/04/13/assionara-souza/. Acesso em 30/10/2019.

WOLF, Christa. Cassandra. Tradução de Marijane Vieira Lisboa. São Paulo: Estação Liberdade, 2007.

WOLF, Christa. Medea: A Modern Retelling. Translated by John Cullen. New York: Nan A. Talese, 1998.

ZELIC, Helena. Durante um terremoto. São Paulo: Patuá, 2018.

Danielle Magalhães (danielle.h.magalhaes@gmail.com) é formada em História (UFF) e é mestra e doutora em Teoria Literária (UFRJ). Atualmente, é bolsista Pós-doutorado Nota 10 pela FAPERJ, com a pesquisa "Mulheres que reescrevem a história".

\section{COMO CITAR ESTE ARTICO DE ACORDO COM AS NORMAS DA REVISTA}

MAGALHÃES, Danielle. "Do segredo à fofoca: mulheres que reescrevem a história na poesia brasileira contemporânea". Revista Estudos Feministas, Florianópolis, v. 29, n. 2, e70608, 2021.

\section{CONTRIBUIÇĀO DE AUTORIA}

Não se aplica.

\section{FINANCIAMENTO}

O presente trabalho foi realizado com apoio da Fundação de Amparo à Pesquisa do Estado do Rio de Janeiro (FAPERJ).

\section{CONSENTIMENTO DE USO DE IMAGEM}

Não se aplica.

\section{APROVAÇÃO DE COMITÊ DE ÉTICA EM PESQUISA}

Não se aplica.

\section{CONFLITO DE INTERESSES}

Não se aplica.

\section{LICENÇA DE USO}

Este artigo está licenciado sob a Licença Creative Commons CC-BY 4.0 International. Com essa licença você pode compartilhar, adaptar, criar para qualquer fim, desde que atribua a autoria da obra.

\section{HISTÓRICO}

Recebido em 12/12/2019

Reapresentado em 15/02/2021

Aprovado em 15/03/2021 